\title{
THE REFLEX "BLEEDING" OF THE COCCINELLID BEETLE, EPILACHNA BOREALIS.
}

\author{
N. E. McIndoo, Ph. D., \\ Bureau of Entomology, Washington, D. C.
}

\section{INTRODUCTION.}

It is a well-known fact among entomologists that when disturbed certain coccinellid and meloid beetles fold the antennæ and legs against the body, eject small drops of liquid from the femoro-tibial articulations and feign death. There has been quite a controversy as to how the liquid is expelled so quickly and as to whether the liquid is blood or is a glandular secretion. Those who believe that the liquid is blood fail to show how it passes through the articular membrane to the exterior, and those who think that the liquid is a glandular secretion do not conclusively prove their view and.they fail to explain how such a large quantity of the secretion can be expelled so quickly.

The phenomenon of ejecting liquid from the femoro-tibial articulations has been called "reflex bleeding." The object of the present paper is to show that the phenomenon is a true reflex, but that instead of the liquid being blood, it is a secretion from hypodermal glands and that it passes to the exterior through innumerable tubes opening near and in the articular membrane.

To obtain material for sections, adult beetles that had been kept in the laboratory all summer were mostly used, although two beetles emerged a short time were also used. Most of the sections were cut five microns in thickness, and all of them were stained with Ehrlich's hematoxylin and eosin. In regard to more details concerning the technique, the reader is referred to the writer's work (1915) on "The Olfactory Sense of Coleoptera."

EXAMINATION OF LIVE BEETLES.

When live individuals of Epilachna borealis are examined without irritation under a low-power lens, they appear wet. The more the beetles are irritated the wetter their integuments become. The entire chitinous integument is more or less covered with small yellow flakes. On the legs and elytra these flakes are numerous, and they may be easily removed with a needle. Beetles in the field eject small drops of liquid from the 
femoro-tibial articulations when only slightly irritated, but after they have been handled and kept in captivity for a short time a stronger mechanical stimulus is necessary to cause them to force liquid from the articulations. Beetles kept in confinement four months with plenty of pumkpin leaves and water were tested to ascertain how many drops of liquid a leg is able to expel in rapid succession. A hind leg was able to eject as many as six small drops with only a few seconds intervening between the emission of any two of them. A middle or front leg was not able to eject quite so many drops. Under a lowpower lens the liquid seemed to come from the articular membrane and from the extreme proximal end of the tibia. Each time the leg was irritated a much smaller drop was also seen on the first tarsal joint.

To determine the strength of the mechanical stimulus required and the mechanics employed in ejecting the liquid to the exterior, beetles were placed on their backs under a lowpower lens. When the distal end of a femur was gently touched with a needle, a muscular contraction instantly folded the tibia against the femur, and a small drop of liquid appeared simultaneously at the articulation. The drop always increased slightly in size after first appearing. A stronger stimulus with the needle was required to bring about the emission of each succeeding drop. The sixth drop, the smallest of all, was produced only by rubbing the entire femur hard with the needle. Legs with the tibiæ folded against the femur can also eject the liquid, but not so easily. Muscular contractions may be noticed in them. Legs held out straight are also able to eject the liquid, but with much difficulty, and muscular contractions are very evident.

The liquid ejected has an amber color and a very offensive odor. It is almost as bitter as quinine and when tasted, a bitter taste lingers in the mouth for almost a half day. It is slightly viscid and dissolves slowly in water. In order to compare it with blood entirely free of any hypodermal glandular secretion, the wings of the same live beetles were cut in two. It will later be shown that the wings do not contain any hypodermal glands, but they are full of blood. Blood from the wings has the same color, the same taste and probably the same odor as the ejected liquid, but the blood is not viscid and it dissolves readily in water and does not sink as quickly as the ejected fluid. 


\section{DISTRIBUTION OF HYPODERMAL GLAND PORES.}

In order to study the distribution of the pores through which the liquid presumably comes, causing the integument to be wet, several specimens were treated with caustic potash twenty-four hours. When removed from the caustic potash, all the tissues were disintegrated leaving only the chitinous parts. When thoroughly washed with water the chitinous integuments were carefully examined.

Minute pores were observed in the chitin of the thorax, abdomen, legs and elytra. The wings contain none of these pores and the head with its appendages were not examined. A single pore (Figs. 1, 6 and $7, p$ ) usually lies near the base of each hair, but sometimes two pores may be seen near the base of a hair. Sometimes a pore lies against the hair socket (Fig. $7, s k)$. When the pores are more numerous than the hairs, they are grouped together and are not associated with the hairs. The pores are most abundant on the legs (Figs. 1-3, p). Besides most of the hairs on the legs being associated with pores, four groups of this type of pore lie near the femoro-tibial articulation and these pores are also grouped together on the tarsal joints. For this reason the region around the femoro-tibial articulation (Fig. 1) contains the most pores of any part of the integument. The first tarsal joint (Fig. 2) contains less and the fourth tarsal joint (Fig. 3) is least well supplied with pores. The thorax (Fig. 6) and the dorsal side of the elytron (Fig. 7) are well supplied with pores, but here the pores are associated with the hairs and are never grouped together.

Another type of pore was found. While examining the articular membranes (Fig. 1, artm) of the femoro-tibial articulations, many minute pores were seen in them. This is the first time that pores are reported in the articular membrane.

The group of pores (Fig. 1, a) always present on either side of the proximal end of the tibia is oval in shape and the chitin containing the pores is lighter in color than the surrounding chitin. In counting the pores in the groups, all the legs of five individuals were used. The number of pores in the groups on the tibæ of the front legs varies from 14 to 25 with 17 as an average; on the tibiæ of the middle legs from 13 to 30 with 20 as an average; on the tibiæ of the hind legs from 18 to 28 with 23 as an average. The general average number of pores in these groups for all three pairs of legs is 20 . 
The group of pores (Fig. 1, b) at the distal end of the femur and near the articular membrane is arranged in a manner more or less like a string of beads (Fig. 4). A group is present on either side of the articular membrane, but both groups on the same femur can never be seen because one of them always lies under a portion of the femur. For this reason the pores in only about a half of these groups were counted. On the front legs the pores vary from 24 to 26 with 25 as an average; on the middle legs from 24 to 37 with 30 as an average; on the hind legs from 29 to 38 with 32 as an average. The general average number of pores in the groups on the femurs of all three pairs of legs is 30 .

On account of the opaqueness of the articular membrane and the small size of the pores found in this membrane, these pores can not be counted, but they are estimated as from 200 to 500 for each membrane

Since the four groups. of pores near the articular membrane and those in the membrane are the only openings, besides a few olfactory pores (Fig. 1, olp) and the pores associated with the hairs, which pass through the chitin at the femoro-tibial articulation where the drop of liquid appears, we must conclude that these pores are the only passages through which the liquid is ejected to the exterior. Counting only the pores in these groups and those in the articular membrane, we see that each tibia has 40 pores, each femur 60 pores, and each articular membrane perhaps 400 pores, making about 500 pores through which the liquid issues. Since all of these pores are so close together the liquid from all of them unites into a drop, while a drop is never seen elsewhere except on the first tarsal joint where there are also many pores near one another.

\section{STRUCTURE.}

In the preceding pages it is shown that the liquid ejected passes through pores in and near the articular membrane. In the following pages it shall be determined whether the liquid ejected is blood or a glandular secretion.

\section{External structure.}

When observed under a high-power lens, the pores in the groups and those associated with the hairs appear as very small light spots. In a vertical view each light spot (Fig. 3, p) is 
bordered by a dark circle inside of which appears a transparent spot that is bordered by a much smaller circle. The internal anatomy of a pore (p. 206) shows what these various parts are. In oblique views the inner circles (Figs. 2, 4 and 5) appear as small wedge-shaped figures.

The pores vary considerably in size. All of those on the tibia (Figs. 1 and 5), all of those associated with hairs on the femur (Fig. 1), and those on the thorax (Fig. 6) and elytron (Fig. 7) are of about the same size. Those in the groups on the femur (Fig. 4) are comparatively large, while those on the tarsus (Figs. 2 and 3 ) are medium in size. Any one of these pores is several times smaller than an olfactory pore (Fig. 1, olp). The pores in the articular membrane (Fig. 8, $p l$ ) are about equal in size to the inner circles of the other type of pore. The tubes connecting with these pores have the same size.

\section{Internal structure.}

Sections through all the foregoing enumerated pores, except those in the articular membrane, show that this type of pore is connected with reservoirs. And furthermore, since both types of pores are the external openings of hypodermal glands, these structures may be designated hypodermal glands with and without reservoirs.

(a) Hypodermal glands with reservoirs.

There is a great difference in appearance between the hypodermal glands in old adult beetles and those in beetles emerged a short time.

\section{(1) Mature hypodermal glands.}

In sections through this type of gland, that part of the structure to be noticed first is the reservoir (Fig. 9, r). It appears as a round or slightly oblong, light-colored cavity. An efferent tube (e) runs from the surface of the chitin into the reservoir and ends about one-third the distance from the bottom of the reservoir. A dark-staining, granular substance is usually seen around the end of this tube in the reservoir. It is now easily seen that the diameter of the light spot in a superficial view is equal to the diameter of the reservoir, and that the transparent spot surrounded by a much smaller circle is the same as the outer opening of the efferent tube. This opening is in reality the pore. 
Just beneath the reservoir lies the pore canal $(p c)$ which is usually narrower than the diameter of the reservoir.

Lying in the hypodermis just beneath the pore canal lies the large gland cell $(g l c)$. On account of its size and the way the hypodermal wall (Figs. 20 and 21) bulges around it, this cell is much more conspicuous than the hypodermal cells. In fact the walls of the hypodermal cells can not be recognized but their nuclei (Fig. 20, hnuc) are distinct. The nuclei of the gland cells (Fig. 9, nuc) are larger than those of hypodermal cells. They are usually round while those of the hypodermal cells are oblong. They generally lie in the broader ends of the cells. Their nucleoli ( $\mathrm{nucl}$ ) are always distinct. The cytoplasm $(c y t)$ is more or less granular. Lying either near the center or in the narrower end of the cell there is a transparent, round area, the ampulla $(\mathrm{am})$, which is usually larger than the nucleus. The ampulla appears to contain radial lines, but on account of the small size of the cells, these lines are almost indiscernible. At the center of each ampulla is always distinctly seen the free end of the conducting tube $(\dot{c})$ whose walls at the free end are darker than elsewhere. Sometimes a dark circle is seen at the center of the ampulla, showing that the conducting tube has been cut in two. This fact shows that the tube is really hollow and is not solid. The conducting tube leads from the center of the ampulla through the pore canal to the reservoir where its. walls unite with the walls of the mouth of the reservoir.

The gland cells vary considerably in size. The largest ones (Fig. 18, glc) are associated with the groups of pores at the distal end of the femur. Those in the elytra are about as large as those widely distributed in the legs.

The reservoirs and pore canals (Figs. 10 and 11) also vary considerably. The reservoirs in the femur near the articular membrane (Fig. 19) are the largest. The pore canals and conducting tubes depend in length on the thickness of the chitin (Figs. 10 and 11) which varies much.

In order to ascertain if the efferent and conducting tubes are chitinous, fresh material containing the femoro-tibial articulations was treated in caustic potash four hours. A study of the sections made from the material thus treated showed that these tubes are composed of chitin (Fig. 12, $e$ and ${ }^{\prime} c$ ). 
(2) Origin of hypodermal glands with reservoirs.

In regard to the formation of the reservoirs and efferent tubes nothing can be said, because they are fully developed when the insect emerges, and no younger stages were preserved in fixing fluids.

When the insect has been emerged an hour, the chitin is about one-third developed. This is seen by comparing Figures 11 and 13. Figure 11 is from an old adult, and Figure 13 is from a beetle emerged one hour. The darker-colored chitin (Figs. 10 and $\left.11, c h_{1}\right)$ is formed before the insect emerges and the lighter-colored chitin $\left(c h_{2}\right)$ is formed after the beetle emerges.

When the insect has been emerged an hour, the gland cells vary in development from undifferentiated hypodermal cells to almost fully developed gland cells. At this stage the hypodermis (Fig. 13, h) is comparatively thick and the hypodermal cells $(h c)$ appear as dark-staining nuclei without the cell walls being visible. The first stage in the formation of a gland cell may be represented by a large hypodermal cell at the mouth of a reservoir (Fig. 13, hc). The second stage is represented by a hypodermal cell that has enlarged sufficiently to cause the hypodermal wall to bulge outward. Its nucleus is now comparatively light in color, its cell wall is discernible, and its cytoplasm is darker than that of the hypodermis. Figure 14, $g l c$, represents such a stage.

The third stage in the development is represented by a gland cell that is forming the conducting tube. All the steps during the formation of the conducting tube were not seen, but enough were observed to imagine the full procedure in the development. A gland cell in the second stage of development is round, or slightly oblong. Now it begins to elongate rapidly and one end begins sending out a process. At this step the ampulla appears and the free end of the conducting tube is formed. The conducting tube is formed from the cellular secretion as rapidly as the process of the cell grows in length. Since the tube at this step often appears as a single dark heavy line instead of two parallel lines, it is probably laid down as a rod of secreted substance rather than as a tube, but later it becomes cylindrical. Gland cells with processes $(p r)$ of various lengths are shown in Figures 15 to 17 . One process $(p r)$ shown in Figure 17 has actually entered the mouth of a reservoir. Now it may be 
imagined that the protoplasm at the tip of the process withdraws and the peripheral end of the tube unites with the walls of the mouth of the reservoir.

By the end of the third stage of development, the gland cells are probably fully developed in size (compare Fig. 16, glc, and Figs. 9 and $10, g l c$ ), but they certainly do not function as gland cells until all the chitin is developed. The thicker the chitin becomes, the longer the pore canals and conducting tubes must be, and the farther the gland cells must migrate into the lumen of the appendage. Up to the time of the fully developed chitin, the gland cells, instead of producing a glandular secretion, produce a chitinous secretion to form the conducting tubes. Perhaps the withdrawal of the protoplasm from the tip of the cell process keeps pace with the lengthening of the pore canal, so that by the time the chitin is fully formed there is no protoplasm surrounding the conducting tube. Now, instead of the gland cells standing more or less vertically to the chitin, they lie parallel to the chitin, and the conducting tubes no longer enter the tips of the narrower ends of the cells, but they enter the sides of the cells usually about midway between the two ends.

\section{(b) Hypodermal glands without reservoirs.}

In a section through the articular membrane (Fig. 18, artm), may be seen one or more small tubes. These are the conducting tubes $\left(c_{1}\right)$ observed in chitinous preparations as shown in Figure 8. They are so small and so transparent that they were not noticed until after this piece of work was almost completed. For this reason, it is not surprising to know that other investigators have overlooked them. They have no reservoirs. Each one pierces the chitin and terminates $\left(p_{1}\right)$ on the surface of the flexible and comparatively thin articular membrane.

A layer of peculiar hypodermal cells had been noticed beneath the articular membrane for some time before the conducting tubes had been observed, but these cells were not given any particular attention until the conducting tubes had been discovered. A careful study of these cells (Fig. 18, $g l c_{1}$ ) under the highest lenses soon showed that they are gland cells like the ones already described except they are several times smaller. Since they are so small their internal structures can not be studied critically. A conspicuous nucleus is always present, but 
the ampulla is generally indiscernible and no tubes were seen running into the cells, although it is common to see the free ends of the tubes among the cells. That no tubes were seen entering the cells is easily explained by supposing that they were pulled out of the cells by the hypodermis withdrawing from the chitin during the fixation. The injury produced by the tubes being pulled out of the cells is certainly the cause of the ampullæ being rarely seen. While examining live gland cells in the honey bee, the writer (1914) found that the slightest injury to the cells caused the ampullæ to disappear.

At certain places the gland cells (Fig. 21, glc $c_{1}$ ) lie bead-like in the hypodermis, causing the hypodermal wall to bulge out around each of them, while at other places they lie in groups (Figs. 18, 19 and $21 g l c_{1}$ ) among the cells belonging to the other type of hypodermal glands.

\section{(1) Origin of hypodermal glands without reservoirs.}

Since no material of pupæ was prepared, little can be said about the origin of these glands, because the conducting tubes are fully developed and the gland cells are being rapidly formed when the insect emerges. When the insect has been emerged an hour, large hypodermal nuclei (Fig. 19, hnuc) may be seen beneath the articular membrane, and many small cells, presumably gland cells $\left(g l c_{1}\right)$, lie in and below the hypodermis among larger gland cells $(g l c)$.

There is no doubt that these gland cells are modified hypodermal cells, but since the conducting tubes pierce the entire thickness of the chitin, they must have been formed simultaneously with the chitin. The conducting tubes belonging to hypodermal glands of the same type in the honey bee are formed as follows: Just before the hypodermal cells begin secreting the chitin, some of them begin sending out processes into the lumen of the abdomen. At the same time other hypodermal cells migrate into the lumen and the processes sent into the lumen unite with the cells that have migrated inward. Each process forms a chitinous tube which runs from the ampulla to the surface of the chitin. By the time the chitin is fully developed, the gland cells are also fully developed, the protoplasm in the processes has been withdrawn from around the tubes, and the tubes are firmly embedded in the chitin. 


\section{HOW REFLEX "BLEEDING" IS ACCOMPLISHED.}

The lumen in the extreme proximal end of the tibia is divided into two almost equal chambers (Fig. 20, $b s$ ) by a membrane $\left(h_{1}\right)$ extending across the leg. In structure and general appearance this membrane resembles the hypodermis with which it unites on each side of the leg. In that chamber containing the nerve $(n)$ and trachea $(t r)$ lie only a few scattered gland cells and only a small amount of blood may be seen in it. The other chamber is full of blood and it is the one that contains all the gland cells $(g l c)$ belonging to the two groups of pores found on the tibia. No muscles are seen in the tibia at this place.

The lumen in the extreme distal end of the femur is likewise divided into two chambers by a membrane. In sections passing through the articulation, may be seen muscle fibers (Fig. 21, $m$ ) at the extreme distal end of the femur, tracheal branches $(t r)$ running to the gland cells $(g l c)$, and a nerve $(n)$ running through the center of the articulation. All the space not filled by the preceding structures may be called blood sinuses (bs).

Under ordinary conditions in the natural environments of the beetles all the reservoirs, conducting tubes and ampullæ are possibly kept constantly full of the glandular secretion. It is reasonable to think that all parts of the cytoplasm of the gland cells are slowly and constantly producing a secretion that flows into the ampullæ from which it gradually passes through the conducting tubes to the reservoirs, if present, from whence it passes through the efferent tubes to the exterior. On the surface of the chitin the secretion forms a small circular film around the exit of each pore. Since this secretion is quite volatile and has an offensive odor, perhaps no further discharge of the secretion is necessary to guard off most of the enemies of this insect. During the constant discharge of this secretion no reflex is called into play.

Since a pore lies near the base of each hair, and as many of these hairs are innervated, a correlation between each tactile hair and the pore near it might at once be suspected. To imagine that the pore lies near the hair for mere protection is not sufficient correlation, because the innervation of the hair would not be needed, if only the protection of the pore is considered. A little speculation, therefore, may not be out of 
place. When a tactile hair is touched, its sense cell is stimulated. Since the sense cells lie near and sometimes against the gland cells, the former may in some unknown way stimulate the latter. If such should be the case, then the gland cells would begin vigorously at once to produce more secretion. And as a result much more liquid would be discharged than ordinarily. If such a relation exists between the gland cells and tactile hairs, the writer can think of no simple reflex better adapted for protecting the insect.

Considering the discharge of liquid at the femoro-tibial articulation, there is no question about the reflex, but whether the stimulus is brought about by pressure on the chitin or by a stimulation of several sense cells belonging to tactile hairs, is an open question. Since only a slight mechanical irritation at the distal end of the femur is required to cause a discharge of the secretion, it is more reasonable to think that the stimulation is brought about by the tactile hairs than by the pressure on the chitin. As soon as the tactile hairs are touched, the muscles contract folding the tibia against the femur and forcing the blood into the chamber containing the gland cells. At once the gland cells are put under a high blood pressure which immediately stimulates them. Instantaneously they discharge all the secretion in their ampullæ causing the secretion in the reservoirs to be shot to the exterior. Now the gland cells without reservoirs play their part by immediately increasing the size of the drop of discharged liquid. Causing drops to be discharged may be continued until the gland cells become exhausted which really occurs after the fifth or sixth drop has been expelled. Each drop is smaller and is discharged less quickly than the preceding one. This shows that the supply of liquid is limited from the beginning, and that a little more time is required for producing each succeeding drop than the preceding one, but if the liquid were blood such would not be the case. It would seem that the liquid secreted under such an emergency would not be exactly the same in composition as that which is produced when the cells are not overworked, but under normal conditions it is perhaps never necessary for these insects to exhaust this glandular secretion.

From the preceding it is evident that the phenomenon of ejecting liquid from the femoro-tibial articulation is a true reflex, but instead of the liquid being blood, it is a hypodermal 
glandular secretion, instantaneously discharged to the exterior under a high blood pressure which is caused by a muscular contraction, forcing the blood into a specially devised chamber containing the gland cells. It is, therefore, seen that the membrane extending across the lumen of the leg plays an allimportant part in the discharge of the secretion, because if it were not present the blood would occupy too much space and could not be put under a sufficiently high pressure to stimulate all the gland cells simultaneously. Furthermore, since the nerve and trachea lie in the chamber containing only a few scattered gland cells, thị may also be a device for protecting these structures against a high blood pressure.

\section{FUNCTION OF THE HYPODERMAL GLANDULAR SECRETION.}

On account of the bitter taste, the high volatility and the offensive odor of this secretion, there is no doubt that its primary function is that of protection. Since we know very little about the ability of the lower animals to distinguish colors, we can not attribute any protecting significance to the color of this secretion, chiefly because the bright amber color is noticed by a person only when drops are ejected from the femoro-tibial articulations. Since these drops are so inconspicuous, it is doubtful whether they are ever seen by an enemy even as large as a bird. Nevertheless, it is quite probable that the amber color is associated with the taste and odor of the secretion.

If the bitter taste of the secretion serves as a means for protecting the insect, it must be granted that the animal seizing the insect can taste and that the secretion in stimulating the gustatory organs of the enemy causes an "unpleasant" sensation. We are certainly safe in saying that the vertebrate enemies (particularly birds) of this insect experience an offensive gustatory sensation when they attempt to eat these beetles. To say that such a sensation is experienced by its insect enemies can not be emphasized, because it has never been conclusively proved that insects can taste.

Since we know that insects as a rule have an acute sense of smell and that the higher animals are also endowed with an olfactory sense, we are safe in assuming that the offensive odor of the secretion is sufficient in most cases to guard off the enemies of this insect. This statement is supported by the fact that most of the common, strong odors, whether pleasant or unpleasant to us, act as repellents to insects. 
The taste, volatility and odor of the secretion seem to be due to a peculiar principle called cantharidine, which is a volatile, acrid, bitter solid, crystallizing into four-sided prisms. It is thus seen why the liquid evaporates so quickly when ejected, leaving yellow flakes on the integument.

A few investigators have performed many experiments with various warm and cold-blooded animals by feeding them some of the secretion. De Bono (1889) used many insects, frogs, toads, guinea pigs and coyotes. He found that the secretion from Timarcha pimeliodes has a manifest action on the heart of warm and cold-blooded animals, and that it has an injurious effect on Musca communis, Sarcophago carnaria, although little or no injurious effect on other insects. Lutz (1895) remarks that the secretion from the same insect may kill flies within a few minutes and is poisonous for warm and cold-blooded animals. Porta (1903) fed the secretion from Coccinella 7 -punctata to various animals. He says that the liquid exercises a poisonous influence upon the organism of both warm and cold-blooded animals, and his experiments show that it is injurious to the brain. He found, however, that it does not exercise any influence upon insects. For Coccinella he thinks that the secretion probably serves as a means of defense by the odor which is offensive to other insects and perhaps this yellowish liquid indicates to them a harmful substance.

The odor of the secreted liquid, besides serving as a means of defense, probably also serves as a means for individual and sexual recognition. The secretion of a given species perhaps emits a specific odor by means of which the different individuals and sexes of that species recognize one another.

\section{DISCUSSION.}

Lacordaire (1838) was one of the first investigators to describe the phenomenon of ejecting liquid from various parts of the body of certain insects. He says that when Dytiscus and Gyrinus are picked up, they emit through the articulations between the head, thorax and abdomen a milky and fetid fluid. Meloe emits from the articulations of the legs a yellowish-orange liquid whose odor is not disagreeable. Coccinellidæ and Chrysomelidæ emit anlanalogous liquid at the same places, but it has a different odor and is quite strong. 
The ejection of a liquid from the articulations of the rudimentary wings of certain Orthoptera has been studied by Cuenot (1896a) and others.

Izquierdo (1896) says that liquids discharged by insects as a means of defense may be divided into three groups: (1) Those from organs which are furnished with glands. Such organs are found in all the families of insects and their exits may be found in the thorax, abdomen, at the anus or in the last portion of the intestine; (2) liquids which are discharged from the femorotibial articulations; and (3) liquids that are discharged from the mouth.

From the preceding it is seen that liquids may be discharged from various parts of the body of insects and that this phenomenon is not restricted solely to beetles.

Leydig (1859) was the first to make sections through the femoro-tibial articulations of Timarcha, Coccinella and Meloe. He thinks that the discharged liquid is blood for the following reasons: (1) No gland cells nor glandular apparatus of any kind were recognized; (2) the discharged liquid and blood have the same color; and (3) the discharged liquid contains presumably blood cells. He admits that this view is not well founded because he could not find any openings in the articular membrane through which the blood could pass.

Cuenot (1890) says that the discharged liquid from the legs of the meloid beetles, Cantharis, Meloe, Mylabris and Cerocoma, is completely odorless, but it is slightly poisonous. He thinks that this liquid is blood, although he did not study sections passing through the articulations. The same author (1894) states that when one touches Timarcha, Adimonia, Coccinella or Meloe, the beetles at once feign death. They fold the legs and antennæ under their bodies, fall to the ground and for a longer or shorter time assume a perfectly inactive attitude destined to deceive their enemies. At the moment when the insects roll on the ground, drops of a slightly viscid liquid are ejected from the mouths of Timarcha and Adimonia, but from the femoro-tibial articulations of the coccinellids and meloids. This liquid is yellowish or reddish in color. The discharged liquid of Coccinella has a strong and very disagreeable odor, and that of Timarcha is odorless, but has a persistent and astringent taste. He proved by experiments that this liquid is for defense. 
Cuenot (1896b) summarizes his investigations by saying that Timarcha, Galeruca, Megalopus, coccinellids and meloids among the Coleoptera, and Eugaster and Ephippiger among the Orthoptera possess the phenomenon of reflex bleeding. When disturbed they feign death and eject drops of blood from the mouth, femoro-tibial articulations and from the articulations of the first pair of wings. In all these species the blood comprises toxic, caustic or repulsive products. It is an important means of defense against lizards and batrachians.

Lutz (1895) asserts that in the Coccinellidæ, blood coming from the distal end of the femur issues through a slit on either side of the articular membrane which surrounds the chitinous rods (Selane) to which the extensors of the tibia are attached. The blood exudes by a forced contraction of the abdomen and by the flexors of the tibia, and it is a voluntary act. It is a means of defense because the blood is actually quite repulsive to insectivorous animals. In Timarcha, Meloe, etc., as in the coccinellids, the device of ejecting blood from the femoro-tibial articulations is to permit the blood to escape from the legs rather than through the mouth.

Packard (1895) states that many beetles, such as the oil beetles Meloe, Cantharis and Lytta, emit drops of blood from the femoro-tibial articulations as a means of defense. The cantharadine produced by these insects is formed in the blood and in the genital organs. It is so extremely caustic that scavenger insects feeding upon the dead bodies of these beetles leave untouched the parts containing cantharadine. Coccinellids are also protected by a yellow mucilaginous and disagreeable fluid which is emitted from the sides of the thorax.

Of those who advocate the view that the discharged liquid is blood, Leydig is the only one who has studied sections passing through the femoro-tibial articulations. And even he admits that his view is not well founded, because he failed to find any openings at these articulations. Lutz has certainly mistaken some other structure for slits. Perhaps he has seen the olfactory pores which often lie where his supposed slits were observed.

The following authors believe that the discharged liquid is a glandular secretion.

Magretti (1881) imagines that the discharged liquid from Meloe is secreted by gland cells in the legs. 
Beauregard (1885) saw a layer of large hypodermal cells beneath the chitin in sections through the articulations of the legs of Meloe. He imagines that these large cells are gland cells.

De Bono (1889) believes that the discharged liquid from Timarcha is a glandular secretion.

Porta (1903) says that the discharge of the secretion from Coccinella, Timarcha and Meloe is caused by a reflex phenomenon brought about by any excitement. The liquid is secreted by a glandular follicle in the reticulum formed from the fibers of connective tissue, situated in the wall of the middle intestine. The liquid has an acrid reaction, and it is perhaps only a bile secretion. He gives three reasons why this liquid is not blood: (1) It is inadmissible that insects should constantly pass such an important fluid; (2) after a prolonged excitation the liquid ceases to exude; and (3) it has an acrid reaction while we know that blood in all animals has an alkaline reaction. He fails to explain how this secretion reaches the exterior from where it is produced.

Berlese (1909) seems to think that the discharged liquid from Meloe is a mixture of blood and a secretion from hypodermal glands. In a diagram showing the anatomy of the leg at the femoro-tibial articulation, he figures a receptacle for containing the blood and shows how the blood is ejected through an aperture at this place in the leg. He also shows unicellular glands lying just beneath the hypodermis on both sides of the articulation. Each gland cell is almost spherical, has a conspicuous nucleus and a central vesicle, the ampulla, from which runs the efferent tube through the hypodermis and chitin to the exterior. These gland cells are like the ones without reservoirs described by the present writer.

Of those who believe that the discharged liquid is a glandular secretion, only Beauregard and Berlese have studied sections passing through the femoro-tibial articulations. Berlese is the only one who has actually found gland cells at this place in the legs. His receptacle for containing the blood is perhaps the same as the special chamber described by the present writer. Since Leydig did not see an aperture in the articular membranes of Timarcha, Coccinella and Meloe, and as the articular membrane of Epilachna does not contain any aperture, it would seem that the aperture described by Berlese was only an artificial 
opening in the chitin made when the material was sectioned. The present writer has examined the femoro-tibial articulations of the meloid beetles, Cysteodemus armatus and Epicauta pennsylvanica. The specimens were first treated with caustic potash and then the chitinous integuments were bleached with chlorine gas. No apertures were seen in or near the articular membranes, but innumerable, almost transparent, minute tubes were observed in and around the articular membranes. Minute gland pores were also seen widely distributed over the entire integument as described for Epilachna.

A survey of the literature pertaining to hypodermal glands shows that these glands vary much in structure.

As far as ascertained by the writer, Hoffbauer (1892) is the only one who has described hypodermal glands having reservoirs in the chitin. These are found in the elytra of Tetropium and Halyzia. The reservoir belonging to the gland in the former species is nothing more than a much expanded efferent canal through which the secretion passes to the exterior. The reservoir in the latter species is similar to that in Epilachna, except its efferent tube is a wide canal. In Halyzia the elongated cells stand vertically to the chitin with their narrower ends uniting with the mouths of the reservoirs. These gland cells have no ampullæ nor conducting tubes.

Tower (1903) found simple and compound hypodermal glands widely distributed in the elytra of Leptinotarsa, Prionus and Orthosoma, but they do not have ampullæ, conducting tubes nor chitinous reservoirs. These gland cells stand more or less vertically to the chitin with their extremely attenuated peripheral ends in contact with the mouths of minute pores.

Casper (1913) found hypodermal glands widely distributed over the entire body surface and appendages of Dytiscus marginalis. In structure they are similar to the ones without reservoirs described in this paper.

Lehr (1914) found hypodermal glands widely distributed in the elytra and wings of Dytiscus marginalis. In structure they are similar to those without reservoirs described by the present writer, except they are much larger. 


\section{SUMMARY.}

Hypodermal gland pores are widely distributed over the entire integument of Epilachna borcalis. Usually one, but sometimes two pores, lie near the base of almost every hair. Besides lying near the bases of the hairs, the pores on the tarsi and around the femoro-tibial articulations lie in groups. Two groups are located at the extreme proximal end of the tibia and two at the distal end of the femur around the articular membrane. All four groups contain 100 pores as an average. The articular membrane contains about 400 pores of another type.

These beetles always appear wet, and the more they are irritated the wetter they become. The wet appearance is caused by a hypodermal glandular secretion passing to the exterior through the pores. When irritated the beetles eject small drops of the amber-colored secretion from the femorotibial articulations through the four groups of pores near the articular membrane and those in the membrane. The discharge of the secretion is accomplished by putting the gland cells under a high blood pressure. This is made possible by a muscular contraction in the femur whereby the blood is forced into a specially devised chamber containing the gland cells which belong to the pores in and near the femoro-tibial articulation.

The gland cells are of two types. Those with reservoirs are several times larger than those without reservoirs. The former are widely distributed throughout the entire insect, while the latter is found only under the articular membrane of the femorotibial articulation. In other respects the two types are alike. Each gland cell has an ampulla and a conducting tube which either runs from the ampulla to the reservoir in the chitin or from the ampulla to the surface of the articular membrane. An efferent tube leads from the reservoir to the surface of the chitin.

The glandular secretion is bitter and has an offensive odor. Its chief purpose is that of protection, but it probably also aids the beetles in recognizing the different individuals and sexes of the same species. 


\section{LITERATURE CITED.}

Beauregard, H. 1885. Recherches sur les insectse vésicants. Journ. Anat. et Phys., Paris, t. 21, Partie 1, p. 511.

Berlese, Antonio, 1909. Gli insetti, vil. 1, 1906-1909, pp. 535-536.

Casper, Alois. 1913. Die Körperdecke und die Drüsen von Dytiscus marginalis L. Ein Beitrag zum feineren Bau des Insektenkörpers. Zeitsch. f. wiss. Zool. Bd. 107, Heft. 1, pp. 387-508.

Cuenot, L. 1890. Le sang des Meloe et le Rôle de la Cantharidine dans la biologie des Coléoptères vésicants. Bul. Soc. Zool. France, Vol. 15, pp. 126-128.

1894. Le rejet de sang comme moyen de défense chez quelques Coleoptères. Comptes Rendus Acad. Sci., Paris, t. 118, pp. 875-877.

1896a. Le rejet de sang comme moyen défense chez quelques Sauterelles. Ibidem, t. 122 , pp. 328-330.

1896b. Sur la saignée réflex et les moyens de défense de quelques insectes. Arch. Zool. Exper., t. 4, (3), pp. 655-680.

De Bono, F. P. 1889. Sull' umoro segregato dalla Timarcha pimelioides. Il Naturalista Siciliano, anno ottavo, pp. 24-28, 44-48, 72-75, 90-95, 121-128, $146-151$.

Hoffbauer, C. 1892. Beiträge zur Kenntniss der Insektenflügel. Zeitsch. f. wiss. Zool., Bd. 54, pp. 579-630. Ueber den Bau und die Lagerung der Drüsen, pp. $616-617$.

Izquierdo, Vicente. 1896. Sobre los liquidos arrojados por los insectos para defenderse de sus emenigos. Act. Soc. Sci. Chili. t. 5, liv. 4, pp. 257-261.

Lacordaire, M. Th. 1838. Introduction à l' entomologie, t. 2, p. 136.

Lehr, Richard. 1914. Die Sinnesorgane der beiden Fluggelpaare von Dytiscus marginalis. Zeitsch. f. wiss. Zool., Bd. 110, Heft. 1, pp. 87-150.

Leydig, Fr. 1859. Zur Anatomie der Insecten. Archiv. f. Anat. Phys. und wiss. Med., pp. $36-38$.

Lutz, K. G. 1895. Das Bluten der Coccinelliden. Zool. Anz. Jahrg. 18, pp. 244-255.

McIndoo, N. E. 1914. The scent-producing organ of the honey bee. Proc. Phila. Acad. Nat. Sci., Vol. 66, pp. 542-555, with one text Fig. and two P1s.

1915. The olfactory sense of Coleoptera. Biol. Bul., Vol., 28, No. 6, with three text figures and two plates, pp. 407-460.

Magretti, Paolo. 1881. Del prodotto di secrezione particolare in alcuni Meloidi. Bollettino Scientifico, Pavia, Anno. 3, num. 1, pp. 23-27.

Packard, A. S. 1895. The eversible repugnatorial scent glands of insects. Journ. N. Y. Ent. Soc., Vol. 3, pp. 110-127.

Porta, Antonio. 1903. Richerche sull' apparato di secrezione e sul secreto della Coccinella 7-punctata L. Anat. Anz., Bd. 22, pp. 177-193.

Tower, W. L. 1903. The origin and development of the wings of Coleoptera. Zool. Jahrb. f. Anat., Bd. 17, Heft 3, Glands pp. 557-558. 


\section{EXPLANATION OF PLATES X AND XI.}

All figures except diagram 21 are from camera lucida drawings made at the base of the microscope. The figures are enlarged as follows: $1, \times 78 ; 2$ to $7, \times 280$; 8 to $19, \times 875 ; 20, \times 350$.

\section{ABBREVIATIONS.}

a-group $a$ of pores on proximal end of tibia.

am-ampulla.

artm-articular membrane.

$\mathrm{b}-$ group $b$ of pores on distal end of femur.

bs-blood sinus.

$\mathrm{c}$ - conducting tube of gland with reservoir.

$\mathrm{c}_{1}$-conducting tube of gland without reservoir.

ch-chitin of beetle recently emerged.

$\mathrm{ch}_{1}$ - chitin formed before beetle emerges.

$\mathrm{ch}_{2}$ - chitin formed after beetle emerges.

ct-connective tissue.

cyt-cytoplasm.

$\mathrm{e}$ - efferent tube.

$\mathrm{f}-$ femur.

glc-gland cell with reservoir.

glc $_{1}$ - gland cell without reservoir.

$\mathrm{h}$-hypodermis.

$\mathrm{h}_{1}$-membrane dividing lumen of leg into two chambers.

hc-hypodermal cell.

hnuc-hypodermal nucleus.

$\mathrm{hr}$-hair.

$\mathrm{m}$-muscle fiber.

n-nerve.

nuc-nucleus of gland cell.

nucl-nucleoli of gland cell.

olp-olfactory pore.

p-pore with reservoir.

$\mathrm{p}_{1}$-pore without reservoir.

pc-pore canal.

$\mathrm{pr}$ - process of young gland cell.

r-reservoir.

sc-sense cell.

sf-sense fiber.

sk-socket of hair.

tb-tibia.

thr-tactile hair.

tr-trachea.

Figures 1 to 8 inclusive are superficial views of external ends of hypodermal gland pores of Epilachna borealis. 
ANNALS E. S. A.

Vol. IX, Plate X.

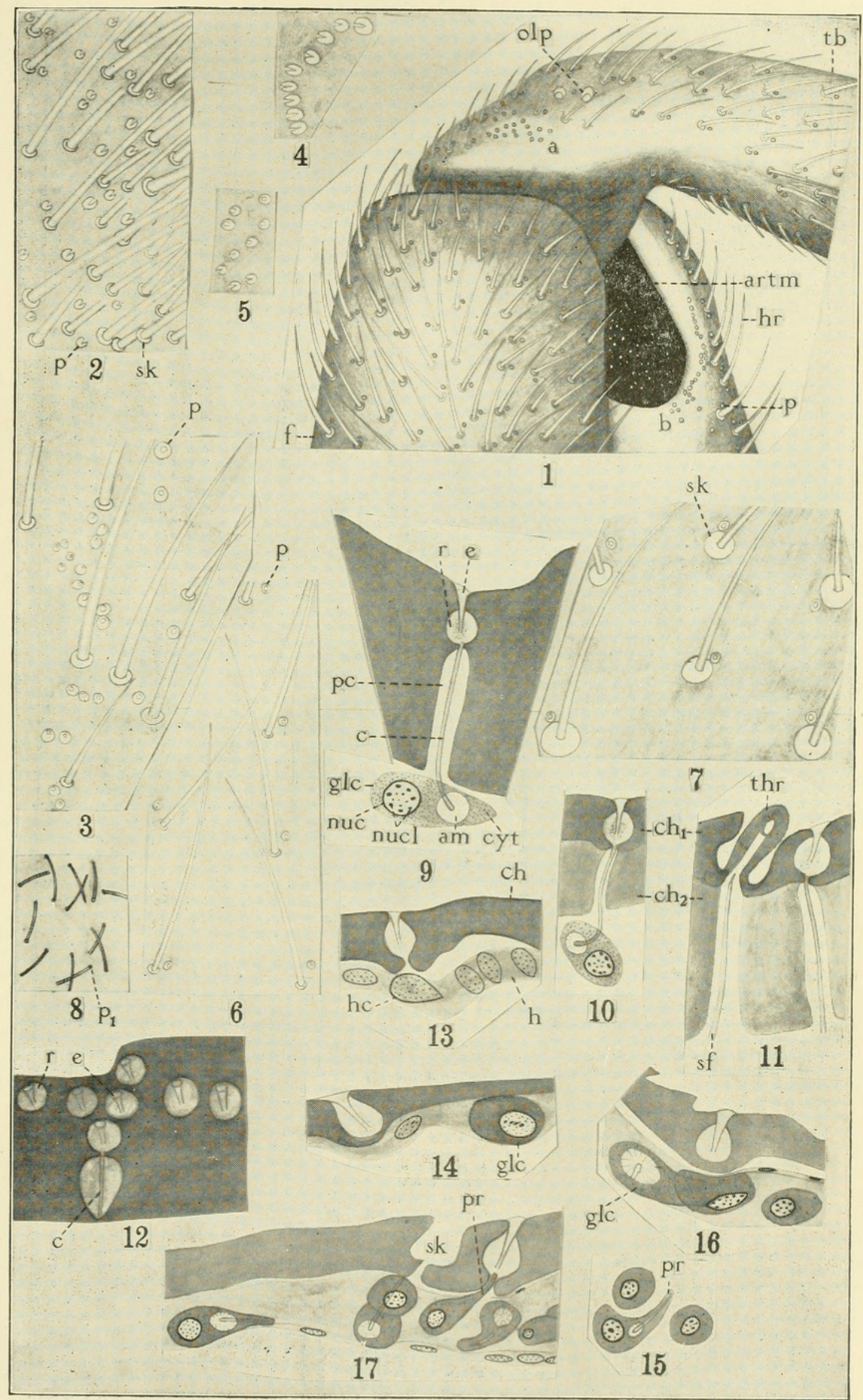




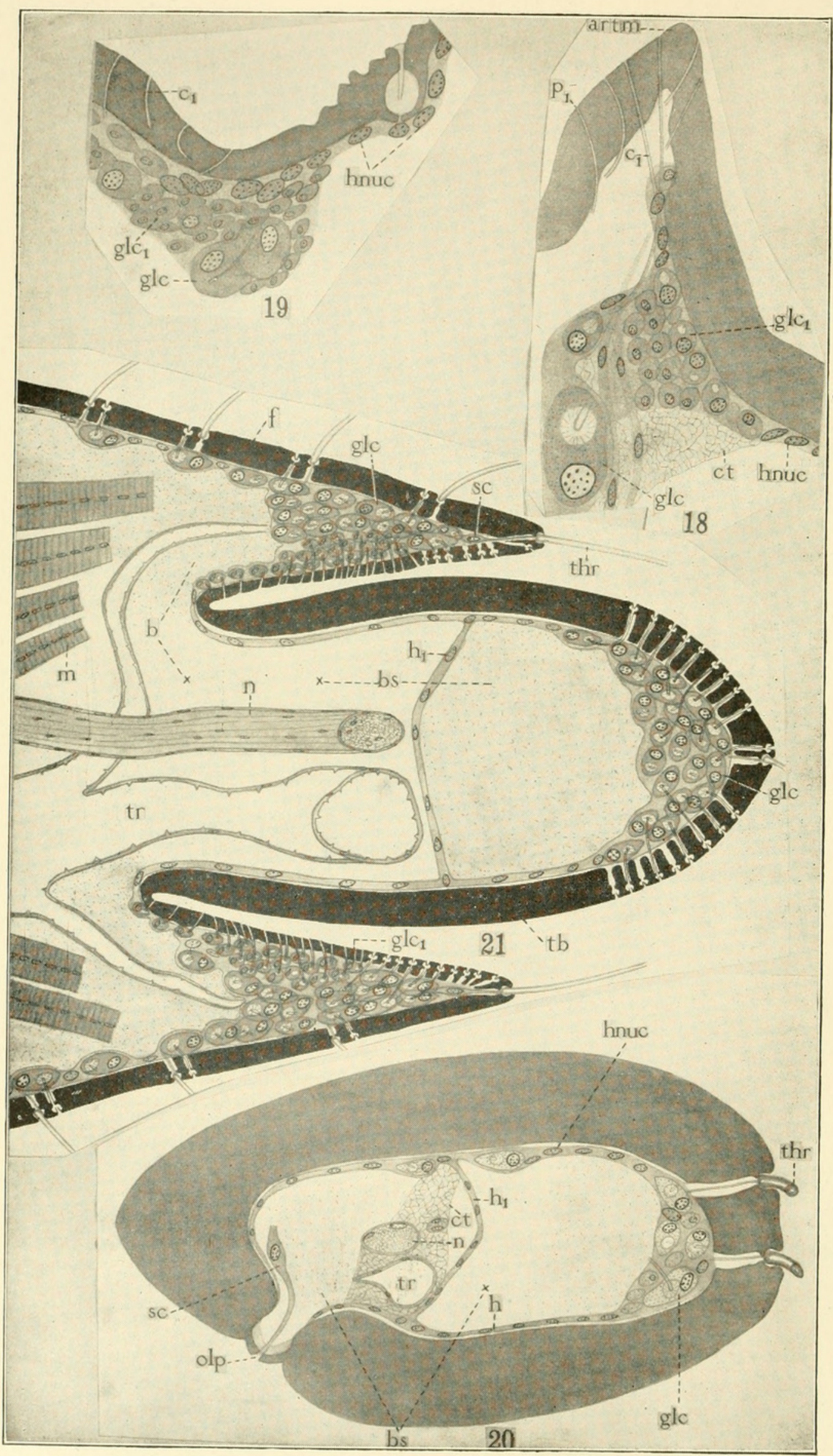


PLATE X.

Fig. 1. Femoro-tibial articulation of hind leg, showing groups $a$ and $b$ of hypodermal gland pores, 3 olfactory pores $(o l p)$, a hypodermal gland pore $(p)$ at base of each hair, and articular membrane (artm) containing hypodermal gland pores (represented by white dots).

Fig. 2. Hairs and pores on first tarsal joint. Oblique view.

Fig. 3. Hairs and pores on fourth tarsal joint.

Fig. 4. Nine pores from group $b$ on femur. Oblique view.

Fig. 5. Nine pores from group $a$ on tibia. Slightly oblique view.

Fig. 6. Hairs and pores from tergum of prothorax.

Fig. 7. Hairs and pores from elytron, near base.

Fig. 8. Chitinous tubes connected with pores, seen by looking through articular chitin.

Figs. 9 to 12 inclusive are cross sections, showing structure of hypodermal glands having reservoirs in old Epilachna borealis.

Figs. 9 and 10. Complete hypodermal gland cells, showing the nucleus (nuc), nucleoli ( $\mathrm{nucl}$ ), cytoplasm (cyt), ampulla ( $\mathrm{am})$, conducting tube (c), pore canal $(p c)$, reservoir $(r)$, and efferent tube $(e)$. Fig. 9 is from thick portion of outer margin of elytron, and Fig. 10 is from proximal end of tibia.

Fig. 11. Gland pore and tactile hair $(t h r)$ pore from distal end of femur.

Fig. 12. Oblique superficial section through tibia, treated with caustic potash 4 hours, showing that efferent tubes $(e)$ and conducting tubes $(c)$ are chitinous.

Figs. 13 to 17 inclusive are cross sections, showing origin of gland cells and conducting tubes of type having reservoirs in recently emerged beetles.

Fig. 13. Four hypodermal cells, one of which $(h c)$ is about ready to change into a gland cell.

Fig. 14. Two hypodermal cells, one of which $(g l c)$ is now enlarged into a gland cell.

Fig. 15. Three young gland cells, one of which is sending out a process $(p r)$ to form conducting tube. Figs. 14 to 16 are from a beetle emerged 1 hour.

Fig. 16. Three young gland cells from thick portion of elytron. One of these $(\mathrm{glc})$ seems fully developed.

Fig. 17. Young gland cells from proximal end of tibia sending out processes $(p r)$ to form conducting tubes. Figs. 17 and 18 are from beetles emerged 24 hours.

Figs. 18 and 19 are cross sections through articular membranes, showing type of glands without reservoirs.

Fig. 18. Conducting tubes $\left(c_{1}\right)$ and gland cells $\left(g l c_{1}\right)$ without reservoirs, and 2 gland cells $(g l c)$ belonging to type having reservoirs from an old beetle.

Fig. 19. Origin of gland cells $\left(g l_{c_{1}}\right)$ without reservoirs from hypodermal cells (hnuc). Also conducting tubes $\left(c_{1}\right)$ and 2 gland cells $(g l c)$ with reservoirs from beetle emerged 1 hour.

Fig. 20. Cross section through extreme proximal end of tibia of hind leg, showing anatomy of leg, including tactile hairs $(t h r)$, olfactory pore $(o l p)$, gland cells ( $g l c)$, membrane $\left(h_{1}\right)$ dividing lumen of leg into two chambers, blood sinuses $(b s)$, etc. The section is 5 microns thick and is from a beetle that had been kept in the laboratory all summer.

Fig. 21. Diagram of a section through femoro-tibial articulation, showing anatomy of leg at this place, including gland cells $(g l c)$ belonging to the two groups of pores on tibia $(t b)$, gland cells belonging to the two groups on femur $(f)$, and gland cells $\left(g l c_{1}\right)$ without reservoirs, etc. The femur $(f)$ is cut longitudinally, but the tibia $(t b)$ is cut across obliquely. 


\section{$2 \mathrm{BHL}$ Biodiversity Heritage Library}

McIndoo, N. E. 1916. "The Reflex "Bleeding" of the Coccinellid Beetle, Epilachna Borealis." Annals of the Entomological Society of America 9, 201-223. https://doi.org/10.1093/aesa/9.2.201.

View This Item Online: $\underline{\text { https://www.biodiversitylibrary.org/item/43630 }}$

DOI: https://doi.org/10.1093/aesa/9.2.201

Permalink: https://www.biodiversitylibrary.org/partpdf/193726

\section{Holding Institution}

Smithsonian Libraries

\section{Sponsored by}

Smithsonian

\section{Copyright \& Reuse}

Copyright Status: NOT_IN_COPYRIGHT

This document was created from content at the Biodiversity Heritage Library, the world's largest open access digital library for biodiversity literature and archives. Visit BHL at https://www.biodiversitylibrary.org. 